\title{
PERILAKU SEKSUAL PRANIKAH MAHASISWA PADA SALAH SATU UNIVERSITAS DI KABUPATEN SUMBAWA
}

\author{
Abyzar Aggasi \\ Program Studi IImu Komunikasi Universitas Teknologi Sumbawa \\ Fakultas Ilmu Komunikasi Universitas Teknologi Sumbawa \\ *Corresponding Author email: abbyzar.aggasi@uts.ac.id
}

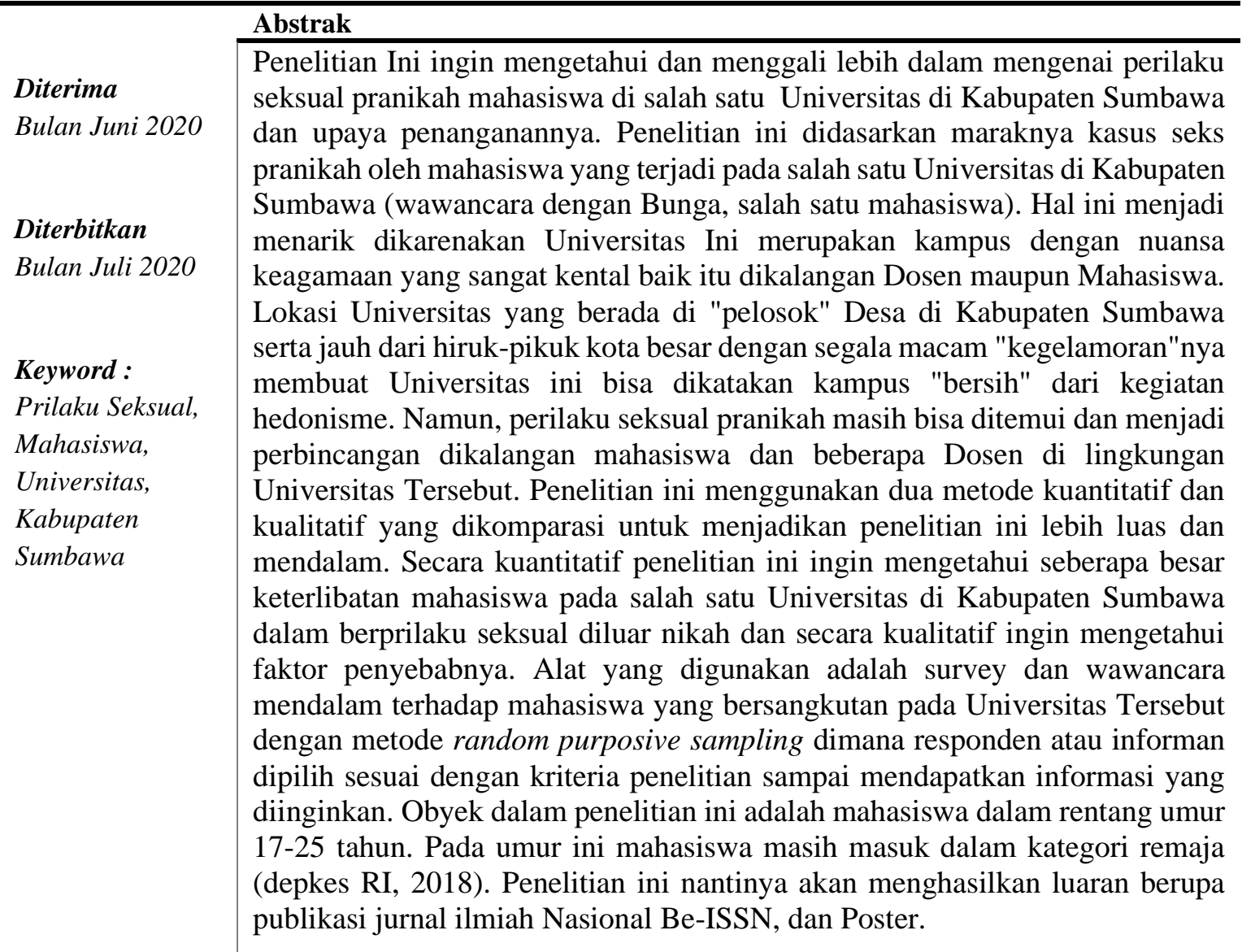

\section{PENDAHULUAN}

Perilaku seks pranikah merupakan permasalahan dan sekaligus fenomena sosial yang sudah sepatutnya menjadi perhatian serius. Prilaku seks pranikah kian lazim dijumpai di dalam Masyarakat saat ini. Pergeseran norma baik buruk, benar - salah, terutama dalam konteks seksualitas semakin jelas terlihat. Pada kelompok remaja, perilaku seks pranikah semakin dianggap normatif dan tidak menjadi hal yang tabu lagi seperti dahulu. Salah satu bentuk perilaku seks pranikah yang paling permisif adalah dilakukannya hubungan seks. Beberapa studi mengenai perilaku seks mengung kapkan angka di mana hubungan seks pertama kali dilakukan di usia muda, sekitar usia sekolah menengah atas atau di awal perkuliahan dengan rentang usia 16 hingga 18 tahun (Rahardjo \& Salve, 2014; Rahardjo, 2015). Mahasiswa sendiri telah lama disebutkan 
sebagai kelompok yang rentan sekaligus juga aktif terlibat dalam perilaku seks pranikah (Uecker, 2015).

Keberadaan salah satu Universitas yang menjadi lokasi penelitan di kabupaten Sumbawa dapat dikatakan sebagai kampus yang agamis dibuktikan dengan latar belakang dosen dan mahasiswa/i yang sangat kuat dengan agama, hampir tidak bisa ditemukan wanita yang membuka aurat di Lingkungan Universitas tersebut, bahkan Universitas tersebut memiliki program keagamaan dimana setiap minggu mahasiswa semester pertama "wajib" mengikuti program keagamaan (Bagian Kemahasiswaan Universitas, 2018)

Kondisi sosial yang agamis memuat Universitas ini menjadi tempat yang sangat menarik untuk dilakukan kajian seputar perilaku seksual pranikah yang terjadi pada mahasiswa. Prilaku seksual pranikah menurut sarwono ( 2003) adalah tingkah laku yang didorong oleh hasrat seksual baik yang dilakukan oleh diri sendiri, lawan jenis, maupun sesama jenis tanpa adanya ikatan pernikahan menurut agama. Irawati (2002) mengatakan bahwa remaja melakukan berbagai macam perilaku seksual beresiko yang terdiri atas tahapan tahapan tertentu yaitu dimulai dari berpegangan tangan, cium kering, cium basah, berpelukan, memegang atau meraba bagian sensitive, petting, oral sex, dan bersenggama. Perilaku seksual pada remaja dapat diwujudkan dalam tingkah laku yang bermacam-macam, mulai dari perasaan tertarik, berkencan, berpegangan tangan, mencium pipi, berpelukan, mencium bibir, memegang buah dada di atas baju, memegang buah dada dibalik baju, memegang alat kelamin di atas baju, memegang alat kelamin di bawah baju, dan melakukan senggama (Sarwono, 2003). Dapat dikatakan bahwa perilaku seksual pranikah adalah tingkah laku yang didorong oleh hasrat seksual yang memiliki tahapan tertentu yang dimulai dari berpegangan tangan sampai dengan bersenggama yang dilakukan oleh diri sendiri, lawan jenis maupun sesama jenis.

Kenyataan bahwa salah satu Universitas yang menjadi Objek Penelitian di kabupaten Sumbawa merupakan kampus agamis yang jauh dari hiruk-pikuk hedonisme harus diakui, namun tidak menutup kemungkinan terlepas dari perilaku seksual pranikah yang dilakukan oleh mahasiswa, maka dari itu penting untuk dilakukan penelitian untuk mengetahui begaimana sesungguhnya kondisi sebenarnya yang terjadi dikalangan mahasiswa sehingga nantinya pihak Universitas dan juga pemerintah daerah setempat bisa membuat treatment khusus apabila terbukti banyak mahasiswa yang terlibat dalam perilaku seksual pranikah sehingga dapat menghasilkan lulusan yang tidak hanya cerdas secara akademik namun juga cerdas dalam moral dan etika sosial.

\section{Kerangka Konsep}

\section{A. Seksual}

Menurut Sarwono (1983), pengertian seks terbagi menjadi dua: Pertama seks dalam arti berarti kelamin, yaitu: alat kelamin itu sendiri; anggota-anggota tubuh dan ciri-ciri badaniah yang membedakan antara laki- laki dan wanita, misalnya: perbedaan suara, pertumbuhan kumis, pertumbuhan payudara, kelenjar-kelenjar dan hormon-hormon dalam tubuh yang mempengaruhi bekerjanya alat kelamin (senggama, percumbuan, proses perubahan, kehamilan, kelahiran).

Kedua, seks dalam arti luas adalah sesuatu yang terjadi akibat dari adanya perbedaan jenis kelamin, antara lain: perbedaan tingkah laku, lembut, kasar, genit, 
dan lain-lain. Perbedaan atribut: pakaian, nama, dan lain-lain. Perbedaan peran dan pekerjaan: hubungan antara pria dan wanita: tata krama pergaulan, percintaan, pacaran, perkawinan atau pernikahan, dan lain-lain

Menurut Rose (1987), seks bukanlah urusan kelenjar saja, adakalanya seks diartikan sebagai pantulan rasa cinta. Oleh karena itu, hubungan seks sering terjadi antara dua orang yang saling mencintai. Lambat laun akan disadari bahwa seksualitas dalam arti luas adalah sesuatu yang luas dan amatlah kompleks. Seks merupakan perpaduan antara perasaan yang membara.

Sarwono (1987) juga menjelaskan seksual memiliki fungsi. Sarwono membagi fungsi seksual dalam tiga bagian Pertama, Seks untuk tujuan reproduksi. Dalam hal ini tidak dibutuhkan persyaratan yang sulit, hanya dibutuhkan dua orang berlawajan jenis dan memiliki tujuan untuk menambah keturunan. Kedua, sarwono menjelaskan bahwa seks berfungsi untuk pernyataan cinta. Seks dalam hal ini juga hampir sama dengan kategori pertama namun dengan tambahan cinta didalamnya sehingga dapat dikatakan lebih kompleks. Dan yang terakhir, Sarwono juga menjelaskan bahwa fungsi seks juga untuk kesenangan dan kenikmatan. Bentuk fungsi ini yang paling sulit diantara kedua fungsi sebelumnya. Disini dituntut kemampuan untuk menghayati hubungan yang cukup lama dan mampu orgasme tanpa merugikan salah satu pihak. Hubungan seks yang merugikan salah satu pihak misalnya terjadi diluar pernikahan dan tidak termasuk kedalam hubungan seks yang benar dan normal.

\section{B. Perilaku Seksual Pranikah}

Menurut Sarwono (2003), perilaku seksual adalah segala tingkah laku yang didorong oleh hasrat seksual baik yang dilakukan sendiri, dengan lawan jenis maupun sesama jenis tanpa adanya ikatan pernikahan menurut agama. Irawati (2002) mengatakan bahwa remaja melakukan berbagai macam perilaku seksual beresiko yang terdiri atas tahapan tahapan tertentu yaitu dimulai dari berpegangan tangan, cium kering, cium basah, berpelukan, memegang atau meraba bagian sensitive, petting, oral sex, dan bersenggama. Perilaku seksual pada remaja dapat diwujudkan dalam tingkah laku yang bermacam-macam, mulai dari perasaan tertarik, berkencan, berpegangan tangan, mencium pipi, berpelukan, mencium bibir, memegang buah dada di atas baju, memegang buah dada dibalik baju, memegang alat kelamin di atas baju, memegang alat kelamin di bawah baju, dan melakukan senggama (Sarwono, 2003).

Peneliti kemudian menggunakan kategori yang dimaksud Perilaku seksual dalam penelitian ini dalam beberapa kriteria menurut yaitu.

\section{Berpegangan tangan}

Berpegangan tangan dalam hal ini adalah kegiatan saling bersentuhan antara laki-laki dan perempuan dengan menggunakan hasrat seksual.

\section{Berpelukan}

Seni berpelukan digambarkan pada mereka yang sedang mabuk cinta. Perkataan cinta berasal dari bahasa sansekerta yang berarti membayangkan. Dengan demikian seni berpelukan diartikan dan berkata dengan membayangkan sehingga kenikmatannya semakin tinggi

\section{Berciuman}

Berciuman merupakan salah satu bentuk mengemukakan rasa cinta yang lazim dilakukan pasangan. Berciuman dalam hal bertemunya bibir masing- 
masing individu laki-laki dan perempuan

\section{Masturbasi/onani}

Masturbasi/onani, yaitu rangsangan yang dilakukan dengan menggunakan jari tangan atau benda lain sehingga mengeluarkan sperma/cairan dan mencapai orgasme. Masturbasi juga dapat diartikan sebagai mencari kepuasan atau melepas keinginan nafsu seksual dengan jalan tidak bersenggama

\section{Petting}

Petting, yaitu melakukan ciuman, gigitan, remasan payudara dan isapan pada klitoris atau penis untuk orgasme. Namun secara teknis pihak wanita tetap mempertahankan kegadisannya

\section{Coitus}

Coitus, yaitu melakukan senggama, dalam bahasa Latin, senggama disebut coitus. Co yang artinya bersama dan ite artinya pergi, sehingga senggama (Coitus) diartikan pergi bersama. Senggama sudah dianggap sebagai pelepasan ketegangan seksual untuk memperoleh kepuasan.

\section{Risiko Seks Pranikah}

Konsekuensi perilaku seks pranikah selain melanggar nilai dan norma agama juga memiliki resiko kesehatan. Adapun Risiko atau dampak seks pra nikah yang dipaparkan oleh Rachmayanie (2017) antara lain:

1. Penyakit menular seksual, bila penyakit ini tidak diobati dengan benar dapat berakibat serius bagi kesehatan reproduksi seperti kemandulan, kebutaan pada bayi yang baru lahir bahkan kematian

2. Dapat terkena penyakit Aquired Immuno Deficiency Syndrome (AIDS) yaitu kumpulan gejala penyakit akibat menurunnya system kekebalan tubuh, dimana penyebabnya adalah Human Immunodeficiency Virus (HIV) dan salah satu cara penularannya adalah melalui hubungan seksual

3. Kehamilan, pada remaja kehamilan di usia yang terlalu dini dapat menyebabkan gangguan pertumbuhan organ-organ tubuh pada janin, kecacatan, sulit mengharapkan adanya perasaan kasih sayang yang tulus dari ibu yang tidak menghendaki kehamilan bayi yang dilahirkannya nanti, sehingga masa depan anak mungkin saja terlantar. Yang lebih berbahaya, apabila remaja yang terlanjur hamil memutuskan untuk mengakhiri kehamilannya atau sering disebut dengan aborsi.

Dalam penelitian lain yang dijelaskan oleh Kasim (2014) dalam penelitiannya yang berjudul "Dampak perilaku seks berisiko terhadap kesehatan reproduksi dan upaya penanganannya" menjelaskan bahwa tidak sedikit remaja laki-laki yang mengidap penyakit kelamin seperti sifilis atau "raja singa", sedangkan bagi perempuan yang melakukannya di bawah umur umumnya mengalami perasaan trauma hingga depresi karena kehamilan ditimbulkan dari hubungan seks tersebut berbahaya bagi organ reproduksi perempuan. Sifilis adalah penyakit kelamin menular yang disebabkan oleh bakteri spiroseta, dan treponema pallidum, karena penularan penyakit ini umumnya terjadi melalui kontak seksual. Tetapi ada beberapa contoh lain seperti kontak langsung dan kongenital sifilis (penularan melalui ibu ke anak dalam uterus). 


\section{Metode Penelitian}

Penelitian ini menggunakan metode penelitian kombinasi (Mixed Method). menurut Creswell (2009) metode kombinasi merupakan pendekatan penelitian yang menghubungkan antara metode penelitial kualitatif dan metode penelitian kuantitatif. selain itu Donna M. Mertens (2010) menjelaskan bahwa penelitian kombinasi merupakan penelitian, dimana peneliti mengumpulkan dan menganalisis data, meng integrasikan temuan dan menarik kesimpulan secara inferensial dengan menggunakan dua pendekatan atau metode penelitian kualitatif dan kuantitatif dalam satu studi. Creswell (2009) juga berpendapat bahwa metode penelitian kombinasi akan berguna apabila metode kualitatif atau metode kuantitatif secara sendiri-sendiri tidak cukup akurat digunakan untuk memahami permasalahan penelitian, atau dengan menggunakan metode kombinasi akan dapat memperoleh pemahaman yang paling baik (bila dibandingkan dengan satu metode).

Desain penelitian ini menggunakan metode concurrent triangulation. Creswell (2009) menjelaskan

concurrent triangulation merupakan sebuah metode penelitian kombinasi dimana metode kualitatif dan metode kuantitati memiliki peran yang sama pentingnya dalam sebuah studi sehingga pengambilan data dan analisis data dilakukan secara seimbang dan bersamaan kemudian dianalisis.

Teknik pengumpulan data yang dilakukan adalah Survey menggunakan kuesioner dengan metode purposive sampling dan sample berjumlah 80 orang yang terdiri dari 40 orang mahasiswa dan 40 orang mahasiswi dari 6 fakultas dan 14
Program Studi. Selain menggunakan teknik survey peneliti juga melakukan wawancara mendalam dengan informan yang akan diwawancarai adalah salah satu mahasiswi terpilih dengan menggunakan metode Snowball untuk menggiring peneliti kepada sumber lainnya.

\section{Hasil Penelitian}

Berdasaran hasil Penelitian lapangan. ditemukan bahwa seluruh mahasiwa/i pada Universitas yang menjadi lokasi penelitian, mengenal seks sebagai hubungan laki-laki dan perempuan yang didasari hasrat dan keinginan dengan tujuan untuk mencari kenikmatan. Beberapa mahasiswa/i memulai Seks pertama kali bersama lawan jenis dengan berpegangan-tangan, berpelukan, dan ada yang langsung berciuman namun ada juga mahasiswa dan mahasiswi yang belum pernah sama sekali melakukan hubungan seks pranikah walau hanya sekedar berpegangan tangan dengan lawan jenisyang berdasar pada hasrat dan keinginan. Jika kita melihat tabel 1.1 mahasiswa cendrung lebih agresif ketika memulai seks pertama kali dibandingkan mahasiswi.

\section{Table 1.1. Bentuk Seks yang dilakukan} Pertama Kali

\begin{tabular}{|l|c|c|c|}
\hline Bentuk Seks & $\begin{array}{c}\text { Mahasiswa } \\
\text { (dalam \%) }\end{array}$ & $\begin{array}{c}\text { Mahasiswi } \\
\text { (dalam \%) }\end{array}$ & $\begin{array}{c}\text { Total } \\
\text { (dalam \%) }\end{array}$ \\
\hline Tidak Pernah & 5 & 7.5 & 12.5 \\
\hline $\begin{array}{l}\text { Berpegangan } \\
\text { Tangan }\end{array}$ & 5 & 25 & 30 \\
\hline Berpelukan & 10 & 12.5 & 22.5 \\
\hline Berciuman & 35 & 11.25 & 46.25 \\
\hline Petting & 0 & 0 & 0 \\
\hline $\begin{array}{l}\text { Berhubungan } \\
\text { Badan }\end{array}$ & 0 & 1.25 & 1.25 \\
\hline
\end{tabular}


Dalam tabel diatas terdapat 1,25\% mahasiswa yang melakukan seks pada saat pertama kali langsung pada tahapan pan berhubungan badan, hal ini disebabkan karena kekerasan seksual yang dialami saat masih anak-anak.

Tabel 1.2

Prilaku Seksual yang Pernah dilakukan Mahasiswa/i Pada salah satu Universitas di Kabupaten Sumbawa

\begin{tabular}{|l|c|c|c|}
\hline Prilaku Seks & $\begin{array}{c}\text { Mahasiswa } \\
\text { (dalam \%) }\end{array}$ & $\begin{array}{c}\text { Mahasiswi } \\
\text { (dalam \%) }\end{array}$ & $\begin{array}{c}\text { Total } \\
\text { (dalam } \\
\text { \%) }\end{array}$ \\
\hline $\begin{array}{l}\text { Hanya } \\
\text { berpegangan } \\
\text { tangan dan } \\
\text { berpelukan }\end{array}$ & 7.5 & 6.25 & 13.75 \\
\hline $\begin{array}{l}\text { Hanya sebatas } \\
\text { Ciuman }\end{array}$ & 21.25 & 23.75 & 45 \\
\hline $\begin{array}{l}\text { Meraba-raba } \\
\text { hingga } \\
\text { masturbasi }\end{array}$ & 12.5 & 10 & 22.5 \\
\hline $\begin{array}{l}\text { Berhubungan } \\
\text { badan dengan } \\
\text { Lawan jenis }\end{array}$ & 3.75 & 2.5 & 6.25 \\
\hline $\begin{array}{l}\text { Lainnya/tidak } \\
\text { pernah }\end{array}$ & 5 & 7.5 & 12.5 \\
\hline
\end{tabular}

Tabel 1.2 menceritakan kondisi saat ini tentang prilaku seksual mahasiswa/i di lingkungan Universitas Sebagaian besar mahasiswa/i pernah melakukan kegiatan seksual walaupun hanya sebagian kecil yaitu 6,25\% yang pernah melakukan kegiatan seksual sampai berhubungan badan.

\section{B. Pengalaman Pertama Melakukan Hubungan Seksual (Hubungan badan)}

Penggalian data dan informasi mengenai hal ini dilakukan dengan survey dan wawancara mendalam dengan mahsiswa/i yang tentunya pernah melakukan kegiatan seks sampai pada tahap berhubungan badan. Identitas informan dalam penelitian ini disamarkan. Ditemukan bahwa pengalaman berhubungan badan paling dini dirasakan pada saat berumur 6 tahun, yang dialami oleh seorang mahasiswi bernama Renita (21 tahun). Renita pertama kali melakukan atau dapat dikatakan terpaksa melakukan hubungan badan dikarenakan tindakan kekerasan seksual yang dilakukan oleh teman ayahnya.

“.... aku dulu dititpin sama temannya bapakku, dulu sering aku sama dua temanku loli sama sofi dipanggil-panggil sama temannya bapakku ini. Dibilang sini-sini kenyot bibirnya, diraba-raba sanpai kita di gitukan (disetubuhi)" (Renita, 21 Tahun)

Semenjak saat itu Renita (21 tahun) mulai mengenal prilaku seksual. Sampai masa SMA dia mulai mengenal laki-laki (berpacaran) dan melakukan hubungan badan secara sadar.

\section{Terbujuk Rayuan}

Perilaku seksual sampai berhubungan badan terjadi sebagaian besar terjadi karena bujuk rayu. Salah satu informan laki-laki menceritakan bahwa dia melakukan hubungan badan pertama kali pada saat SMA. Dia penasaran karena sering menonton video porno kemudian mengajak pacarnya untuk melakukan hubungan badan atas dasar cinta. Wahyu (20 tahun) nama samaran, menjelaskan bahwa pertama kali melakukan hubungan badan di kos-kosan teman. Saat itu dia mengajak pacarnya yang juga mahasiswi 
di salah satu Universitas di kabupaten sumbawa untuk mampir di kos teman dengan alasan main. Sampai di lokasi dia memberikan isyarat pada temannya untuk pergi sehingga dia bisa berduaan dengan pacarnya. Saat itulah terjadi bujuk rayu beralasan cinta dan terjadilah hubungan badan.

“....dulu pertama kali dikos teman. waktu itu sengaja saya ajak pacar saya main ke kos teman saya. sudah saya telpon dia (temannya) duluan supaya nnti pinjam kamarnya. ee.. sampai di kos langsung saya kasih kode ke teman. dia ngerti sih. langsung dah saya rayu pacar saya disitu sampe mau gituan..." Wahyu (20 tahun)

\section{Perkosaan}

Perkosaan terjadi pada dua orang Informan wanita dalam penelitian ini. Wanita pertama yaitu Renita (21 Tahun) seperti yang kita ketahui sebelumnya bahwa dia telah disetubuhi oleh teman ayahnya pada saat berumur 6 tahun. selanjutya ada Erna (20 tahun) nama disamarkan, mengaku bahwa pertama kali melakukan hubungan badan karena dipaksa meminum minuman keras oleh temannya sendiri kemudian di setubuhi oleh teman yang lain ketika dia sudah dalam kondisi mabuk berat.

“.....iya dulu pertama kerena mabok. dipaksa minum sama teman saya, bodohnya saya mau aja waktu itu minum. abis itu teman saya yang laki di raba-raba badan saya, sampe akhirnya nda bisa tahan saya....” Erna (20 tahun)

Korban pemerkosaan memiliki kemungkinan mengalami setres paska perkosaan yang dapat dibedakan menjadi dua yaitu stres yang langsung terjadi dan stres jangka panjang. stres yang langsung terjadi merupakan reaksi paksa perkosaan seperti kesakitan secara fisik, rasa bersalah, takut, cemas, malu, marah, dan tidak berdaya. sedangkan stres jangka panjang merupakan gejala psikologis tertentu yang dirasakan korban sebagai suatu trauma yang menyebabkan korban memiliki rasa kurang percaya diri.

\section{Faktor Resiko Berperilaku Seksual Pranikah.}

Ada berbagai faktor yang menyebabkan mahasiswa/i berprilaku seksual pranikah.setidaknya dikelompokan menjadi faktor internal dan faktor ekstrnal. Berdasarkan Hasil Survey dan wawancara mendalam yang dilakukan faktor Internal dapat dikategorikan menjadi Keluarga dan diri sendiri, lalu faktor Eksternal berasal dari kondisi pertemanan dan lingkungan.

\section{Keluarga}

Keluarga merupakan faktor penting dan paling dasar terhadap prilaku anak. dari hasil survey yang peneliti lakukan, 87\% menyebutkan bahwa peran keluarga yang kurang baik menyebabkan prilaku anak menjadi bebas dan tidak terkendali. Pengakuan Renita (21, Tahun) mengatakan bahwa sejak kecil dia tidak mendapatkan perhatian orang tua, ibunya bekerja sebagai TKW di Hongkong dia sering ditinggal ayahnya bekerja dan sering pula dititipkan kepada teman ayahnya.ketika dia beranjak dewasa, ibunya kembali dari hongkong untuk mengurusi ayahnya yang terkena penyakit stroke, Renita merasa kesepian dan mencari pelampiasan.

“...aku ngerasa kesepian saat itu nda ada yang perhatikan aku, nda ada yang lindungin aku saat itu, kan bapakku sakit-sakitan jadi semua fokus ke bapakku semua keluargaku.... aku suka pusing akhirnya larilah ke pacar. saat itu pacarku namanya jimmi, dia yang buat aku nyaman..." 
menurut agaid (2002). keluarga merupakan pihak terdekat bagi korban, selalu bersikap tenang, dan berusaha mempercayai cerita yang disampaikan dapat membntu korban merasa tenang. Keluarga mempunyai peluang yang banyak untuk mendampingi korban melewai masa-masa sulit akibat perkosaan yang dialaminya. mereka dapat memberikan dukungan dengan selalu meberikan rasa aman kepada korban, menerima keadaan korban apa adanya, tidak menyalahkan korban atas apa yang terjadi padanya, bersikap tulus dalam berhubungan dengan korban baik verbal ataupun nonverbal.

\section{Lingkungan}

Faktor lingkungan merupakan faktor yang penting yang dapat merubah prilaku mahasiwa/i yang sedang dalam pencarian jati diri. Perkembangan mental dan spritual yang baik dibangun dalam lingkungan yang baik begitu juga sebaliknya. Pergaulan Mahasiswa/i tidak hanya dengan sesama almamater saja, namun juga dengan yang lain. seperti yang sudah kita ketahui sebelunya Erna (20, Tahun) terlibat pergaulan bebas sampai akhinya menyeret dia kedalam Prilaku seksual Pranikah (berhubunga bandan).

lingkungan yang tak terkontrol dapat memberikan pengaruh negatif dalam pergaulan, kurangnya dukungan dari orangorang terdekat sepeti keluarga, orang tua, saudara ataupun teman dapat menyebakan terjadinya prilaku seks menyimpang kurang perhatian sehingga mencoba untuk mencari suasana di luar kebisaanya, masuk ke lingkungan yang tidak terkontrol, seperti pacaran karena terlalu sering bersama hingga lupa batasan karena sudah merasa nyaman.

\section{Eksistensi Diri}

Ada hal menarik dalam penelitian kali ini, yaitu salah satu faktor yang dapat menjerumuskan mahasiswa/i adalah eksistensi diri. Maksudnya bahwa seorang remaja tentunya ingin menunjukan suatu hal dapat meningkatkan eksistensinya dalam pergaulan. misalnya dengan melakukan hubungan seksual kepada pagangannya menjadi bahan perbincangan dikalangan mahasiswa laki-laki. Menurut peneliti eksistensi diri ini merupakan hal yang sangat berbahaya bagi pergaulan mahasiswa/i, karena ini dapat mendorong keinginan lebih yang tak berakhir.

seks pranikah akan terjadi jika pelaku tidak dapat mengendalikan dirinya dalam memenuhi gairah seksual. permasalahan seksualitas muncul secara alami bersamaan dengan perkembangan psikologi dan sosial remaja dimana mereka tertarik dengan lawan jenis dan keinginan untuk mencoba membangun hubungan yang sangat kuat diantara keduanya. Keinginan dan kegiatan seksual harus dilihat sebagai kecendrungan alami dan naruri yang akan datang ketika mereka dibutuhkan dan diperlukan . seksualitas melibatkan fisik, pribadi dan aspek simbolis yang terhubung langsung dengan hubungan seks. kurangnya edukasi dan sosialisasi tentang seksualitas pada remaja dapat menyebabkan salah satu permasalahan seksualitas yaitu pre- marital sex (seksual pranikah) yang melampaui batas dan norma dan nilai dalam masyarakat. 


\section{Kesimpulan dan Saran}

Mahasiwa/i di salah satu Universitas di kabupaten Sumbawa secara sadar mengetahui apa yang dimaksud dengan Prilaku Seksual. Peran Keluarga, lingkungan dan Pergaulan sangat berdampak bagi prilaku mahasiswa/i tersebut. Ada hal yang menarik terjadi di lokasi Penletian yakni salah satu Universitas yang berada di Kabupaten Sumbawa, ternyata kampus yang memiliki nuansa Islami tersebut tidak bisa memaksa mahsiswa/i untuk memiliki akhlak yang Islami. Perilaku seksual memang bukan hal yang bisa dipaksakan karena menyangkut hak dan dilakukan secara privat namun peneliti Peneliti menyarankan bagi Institusi Pendidikan tinggi khususnya pada salah satu Universitas yang menjadi lokasi Penelitian di Kabupaten Sumbawa untuk lebih meningkatkan kegiatan yang bisa membangun akhlak yang baik bagi mahsiwa/i yang kelak akan menjadi penerus bangsa.

\section{REFERENSI}

Agaid, N.2002. Penyerangan Seksual terhadap anak atau Perlakuan Salah secara Seksual Terhadap Anak

Creswell, Jhon W. 2009. Research Design: Qulitative, Quantitative, and Mixed Methodes Approaches. Newbury Park:Sage Publications.

Fajrin Kasim.2014. Dampak Prilaku Seks Beresiko Terhadap Kesehatan Reproduksi dan Upaya penangananya.
Irawati N. 2002. Panduan Penatalaksanaan Terkini Rinitas Alergi, Dalam: Kumpulan Makalah Simposium "Current Opinion in Allergy and Clinical Immunology" Devisi Alergi-Imunplogi Klinik FK UI/RSUPN-CM, Jakarta.

Mertens, D.M. 2010. Research and Evaluation in Education and Psychology: Integrating Diversity With Quantitative, Qualitative, and mixed Methods. (3rd ed). Thousand Oaks, CA:Sage.

Rose, Michael R.1983. Quantitative Ecological Theory:an Introduction to Basic Models.Crom Helm, London and Sydney

Ririanti Rachmayanie. 2017. Seks Pranikah Sebagai Problematika Remaja Sekolah Menengah.

Sarwono.2003. Dasar-dasar Metode Penelitian Klinis, Raja gravindo Persada, Jakarta.

Sarwono, Sarlito Wirawan. 1983. Problem anda:Masalah Remaja: Pacaran dan Kegiatan Belajar, Rajawali.Jakarta.

Sarwono, sarlito Wirawan, dan Marvin E.Shaw; Philip R.Costanzo. 1987. Teori-teori Psikologi Sosial. Rajawali. Jakarta. 